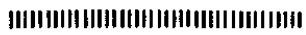

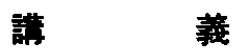

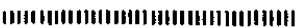

\title{
新商品開発方法論( 1$)^{*}$
}

瀬 川 正 明 ${ }^{* *}$

\section{I.はじめに}

2. 序 説

2.1 ある織維メーカーの菜材開発成功要因

2.2 織維製品（あるいは商品）の開発

3. 新製品開発の原理

3.1 企業と新製品開発

3.2 新製品開発の概要

3.3 新・弊品・開発の意味

3.4 現代当面の開発ポイント

4. 繊維商品開発の方法
4.1 新商品の開発パターン
4.2 繊維商品の開発システム
4.3 開発方法

（太字は本号掲載分）

\section{I.はじめに}

本誌編集部から，新商品開発について，それも繊維商 品を中心にした，開発の方法論的なことを述べるよう依 頼があった. 簡単にお引き受けしたが，いさ執筆しよう とすると，誰を対象にして，どの範囲のことを，どの程 度に書くべきかということに迷い，執筆か延し延じにな ク，とうとう約束の締切日になってしまった。本誌では 3 回にわたり，前揭の事項について述べることとする。 内容は学術論文ではなく，企業で繊維関係の開発に従 事する方々にいくらかでも参考にしていただけたらとい う立場で，開発のすすめ方を中心に述べることにする。

2. 序 説

\section{1 ある識維メーカーの開発成功要因}

いささか順序が前後するように思われるであろうが, はじめに，ある繊維メーカ一の開発について述べよう。 それも, 開発テーマの設定, 研究, テスト, 工業化, 試 販といった一連の開発ストーリーは紙数の都合で後述す ることにして，開発成功の要因を考えてみたい，それは， 開発をすすめる上でのポイントは何かということについ て考えるときの資料になると思うからである。

いろいろな㵶維素材があるか，英国 I C I から帝人・ 東レが技術導入したテトロンについて，取上げてみよう。 テトロン（衆知のことと思われるがポリエステルのプラ ンド名）の開発は日本の企業の中でも代表的な成功事例 の一つであろう。その成功理由は，いろんな角度から見 ることができるし，多くの要因を指適できるが，要約す れば

1）開発環境とタイミングが熟していた

2）製品あるいは商品および用途がよかった

3）開発のマネージメントが適切であった

4）上手に作り，上手に売つた

5）顧客を創造し，顧客に買っていただけた ということになろう. 個条書きにすると数行のごく平凡 と思われるような項目になるが，これは，SRI（Stanford Research Institute) が「企業の成長要因」とし であげている。

1) 既存分野での競争力を確立すること

2）成長機会を組織的かつ継続的に求めること

3）危険をおかす勇気があること

4）成長分野の中，もしくはその周辺にいること

5）幸運あるいはチャンスの作用をともなうこと といった 5 要件を備えることができたと表現しなおして

* A Theory of New Commodity Development.

**M. Segawa, 帝人 管理技術部 主席部員 
もよかろう，以下開発の成功理由についてもう少し説明 しておこう.

（1）開発罟境とタイミングが熟していた。

(1) 当時日本では, レーヨンが衰退期に入ってレーヨ ン企業の斜陽化が嗄されていた。一方東レのナイロ ンは脚光をあびはじめており，各企業は次代の絓維 を模索中で，いわば繊維産業の転換期であった，市 販されている合成繊維はまだナイロンだけであり， 東レ, 日レの2社によって生産が行なわれていた。

(2) 天然 再生，化学各瀻維に対し，ナイロンに代表 される合成織維のよさや，特徵がようやく認識され つわる時に, 合縺第 2 弾としてテトロンが登場し た.すなわち未厤の荒野に突如として新しい合瀻が 出現したものではなく，ナイロンの開発努力により， つぎの合繊が入りやすいように，技術面，販売面か らみて, 織物, 加工，流通，消費者の開発を容易に する基盤ができあがりつつあった。

(3) この時点で，日本における先発としてテトロンを 取上げ，しかも後発 3社が参加してくるまでの6年 間 (昭和 33 昭和 39 ), 帝人，東レの 2 社のみで 生産販売にあたった. 先発の有利性と市場の富占に より創造者利潤を獲得した。

(4) 帝人と東レはIC I から技術導入し同時に開発を スタートしたが開発スピード，製品品質，コスト， 市場開発，顧客のP R と獲得……...など, 開発を刺 激し合い，このために一社のみでやるよりも短期間 に生産販売体勢を碓立することができた，しかも巧 みに最当競争を避け、「良い意味の競争」のメリット を発揮した。

(5) テトロンは日本においてはもちろんはじめての新 製品であるが, 欧米においてもまだ尊入期の段階で あって解決すべき課題は沢山あった. しかし企業化 という観点からすれば, 技術面, 製品面, 販売面, においてほほ完成しつつあった。すなわち海のもの とも山のものともかからぬ世界ではじめての新製品 ではなく，取上げれば苦労はあってもほほ（確実に） 成功を見通せるような製品であった。

(6) また昭和 34 年一昭和 36 年は池田内閣の時代であ $\eta$ ，所得倍増計画とか岩戸景気など呼ばれた高度経 済成長期であり，多くの産業は生産，眅売，消費を 順調に应大していた，中でも合瀻テトロンはその代 表的事例であり，たとえば $5 \rightarrow 15 \rightarrow 30 \rightarrow 60$ t/dayというように倍ましの增設を続けた。

(7)一方原油を原料とする石油化学工業は，開花発展
期であり，製品の種類も品質も生産量もめざましい 桩大と向上をとげつつあった。この石油のおう盛な゙ 需要に対応し, 造船技術, 海運業のめざましい発達 と相まって石油は，大量安価にしかも安定して入手 可能となりこれを原料とする石油化学製品 (PX, EGなど）も，大量安価に安定して確保され，テト ロン原料として供給きれた。すなわち産業の相互循 環により，よい原料やエネルギー（電力）を得るこ とができた。

（2）製品（あるいは用途）がよかった。—よい開発テ 一マであった

(1) 特許で保護された製品であり，ノウハウがあっ た。

(2) 䋞維自体の物理的特性（たとえば強度，伸度…… など）が他の緘維にくらべきわめて優れたものであ った.

(3) このテトロンを使用して商品（衣服）にしたとき 他の䋞維にない，性能，機能，特徵があった。た えば 3 W特性（洗ってすぐ着られる.しわにならな い，取扱いが容易である）といわれる性能か商品と してのすばらしい競争力になった。

(4) 原料素材形態として, 長瀻維 (フィラメント) と しても短繊維（スフ）としても，どちらにも用途が あった。

(5)すぐれた物性のゆえに，衣料用，インテリア用， 産業用などあらゆる絒維市場に幅広い用途があり。 適用できた。

(6) 用途を衣料用に限っても，合繊として目新しいも のであり，かつ，今までのどの繊維にくらべても， 本格的万能的な繊維であった（ちなみにナイロンは， 肌着あるいは工瀻用，インテリアが主体).

(7)とくに日本の気候風土や好みによく適合した瀻維 であった。

(8) オール シーズン性であった（アクリルは秋冬が主 体である).

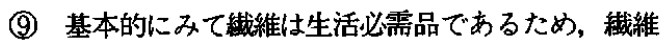
市場は長期的に需要か安定している，その上，テト ロンは技術革新性（新素材，新加工処理）をもって おり，付加価值性に富み，成長性のある瀻維であっ た.

（3）開発のすす女方——開発マネジメントが谪切であっ た

(1) 開発渴望, 期待の背景 斜陽化する繊維, レーヨンのみに依存していな帝 
人としては，躍進発展を続ける十イロンにより，東 レに大きく企業格差をつけられ，帝人のトップ以下 全社員は，危機意識とともに新事業を晹望し，全社 員が燃えていた。

(2) 当時は 3 大合緎（十イロン, ポリエステル, アク リル）の導入期であり，何をどのように企業化すべ きかという決断は神のみぞ知る困難事であるが， 3 大合織の中からただ1つポリエステルを選んだ. 3 鬼を追わず 1 兔を追うこと，しかもねらった1鬼の 優位性と将来性を洞察するトップの判断力, 決断力 の有無は，開発の成否を分つ重大要件である。

(3) 企業における組織活動で, 平凡なことと思われ， かももっとも大切なこと，それは組織の全員が共通 の理念，共通の目的と目標に向って一致協力して取 組むことである．社運をかけてテトロンを開発する が, 何としてむ成功しなければならないという気迫 のもとに全社の人，金，技術，情報…...などの開発 資源趿員され，結集された。

(4) テトロンの開発は,トップから末端にいたるまで, 開発使命, 開発方針, 開発計画について徹底してい た. そしてあたかも特別お召列車を走らせるごとく， 何ものにも優先して開発業務が進められた。

(5) 開発に参画する各機能 (調查, 企画, 研究, 開発, 建設，生産，販売，販促など)は，燃えるような熱 意をもってしかも適確でスピーディーな䘕動をした。

(4) 開発のすす方一一技術・生産関係

(1) 一般に研究開発というものは, 大きな開発資源

(人，金，物，時間）を必要とし，しかも成功の確 率の低いリスキィーなものであるが，テトロンの開 発は, I C I 社より, 特許, ノウハウを導入した ものであり，したがって基礎研究・開発研究を省略 することができ，開発費の低減とリスクを回避する ことができた。

(2) レーヨンのパイオ二ア, トップメーカーとして の自信，長年にわたる各種繊維についての生産と加 エに関する技術，蓄積，そして多くの技術者，これ らが技術導入の消化を容易にし, 開発の各ステージ で活用された。

(3) 開発初期においては, 開発のスピードをあげるた めできるだけ品種を少なくし，品種の確保，安定化， コスト低減，織物生産技術, 加工技術の確立を強力 に進めた。.またたえず競争会社，東レ製品との比較 が考慮された。

(4) 新素材としで新品種がつぎつぎと開発された.
たとえば，テトロン゙ スフを例にあげると，T-89， $\mathrm{T}-70, \mathrm{~T}-65, \mathrm{~T}-61, \mathrm{~T}-38, \mathrm{~T}-$ $36, \mathrm{~T}-33$ ……なとの品種が市場ニーズに対応 して開発された。

(5) テトロン導入時点で, すでにナイロンの開発に成 功した実績をもつ東レと，合械を手がけたことのな い帝人との技術格差，したがって開発の優少差につ いて，世上の話題になったが，それだけに技術陣は 東レを意識して,「1日でも早く，1月でも安く，1 トンでも多く……」を相言葉にして建設と生産に取 組んだ.

(6) 徹底した合理主義に基づく品質とコストに対する 挑戦が続けられ，つぎつぎに工程改善, 設備改良の 手がうたれた。たとえば,

1)バッチ方式による重合サイクルは，8hr/バッ チ $7 \rightarrow 6 \mathrm{hr} /$ バッチというようにスピード アップされた。

2)重合におけるへンケル法が改良され，さらには直 重技術が完成した。

3)チップ乾燥工程が合理化され，安定した水分率管 理がされるようになった。

4)ダブルタンデムなど紡系延伸工程設備の大幅な 改善が行なわれた。

などをあげることができる，導入された技術は，やが て I C I に逆導入されたり，イーストマン社に技術輸 出されるなどすばらしい向上と発達をとげた。

(5) 開発のすすめ方一一販売関係

(1) 流通对策：百貨店，専門店を中心にセールス チ 一ムを作りチーム活動で谁めた。

(2) 加工対策：緊密な協業体制を作り上げ，系列化对 策が進められた.プロダクション チームの育成に カを入れた。

（3）顧客対策：情報提供に力を入れ，マスコミ媒体を 大いに活用した。

(4) 販売対策：内地衣料用分野を焦点にし，基本品種 を中心として，チョップ織物を中心とする眅売が進 められた。

(5) 洒格政策：建值制をとった.

(6) テトロンの製品商品としての品質性能がすぐれて おり, 顧客の要求を渵足させた.

(7) 需要はおう盛であり,かつ急激に伸長したが, 供 給が追いつかす，開発期は需要過剩（品不足, 売手 市場）であった。

（8）長年にわたる化緘の流通経路，強固な販売地盤が 
フルに活用された。

(9) 綿混用スフの拡大 (ホンコン シャツ) P P加工. による綿混の再拡大, ウーリ一加工によるフィラメ ントブームの到来などつぎつぎに新加工法，新用 途加開発早れた。

(10)衣料分野のみならず，非衣料分野(インテリア) や産業資材分野（タイヤコードや沪布，视布など） 新しい用途開発を行なった。

(11) 東レと協同でネーミングをし，商品イメージを分 散させず 1 本化した。

(12) 各用途商品の要求特性を, 天然繊維との比較で分 析し，各用途にマッチした素材構成，織組織を研究 するなどセグメント販売を徽底させた。たとえば， 下表のとおりである。

\begin{tabular}{|c|c|c|}
\hline 用 途 & 商品 & 素 \\
\hline 紳士用 & $\begin{array}{l}\text { シャ } ツ \\
\text { 紳.士 服 }\end{array}$ & $\begin{array}{l}\text { テトロン/綿 } \\
\text { テトロン/羊毛 }\end{array}$ \\
\hline 婦 人 用 & $\begin{array}{l}\text { スカート } \\
\text { スラックス } \\
\text { ブラウス }\end{array}$ & $\begin{array}{c}\text { テトロン /レーヨン } \\
\| \quad / " \\
\| !\end{array}$ \\
\hline
\end{tabular}

(13) 東レとの提携，たとえば商標，建值制，スフにお ける混率規制，ラベル管理などを提携して不必要な 泥仕合を避けな。

(14)適切なキャンペーンを行なった.テトロンキャ ンペーンは従来にない華やかなもので常にマスコミ の好材料になったが, 顧客に対する企業イメージ，

製品イメージアップの影響は大きなものがあった。

(19) テトロンの開発は, 商品開発, 用途開発であった。 たとえば; ホンコンシャツ，トリコットシャツ， カスタムシャツ, パーマシャツ,カラーシャ ツなど, 一連のシャツキャンペーンにその一例を 見るごとく，つぎつぎにテトロンの機能を追求し， 新品種，新用途の開発が進められた。

（6）顧客に買っていただけた。

(1) 国の経済成長が著しく, 購買力, 消費力が大きく 伸びた。

(2) 食の充足についで衣料の充足期に入り，衣料の需 要がおう盛であった。

(3) やがて単なる必需品としての衣料からファッション としての衣料が求められ，依然として需要が続いた。 (4) 消費生活に打ける合理化，多様化，高級化の要求 と，衣料の合縺化とがむすびついた。

\section{2 織維製品（あるいは商品）の開発}

前項では，ある繊維素材メーカーの開発を事例として 成功要件を考えてみた，しかし，これは緎維に関係する 産業のごく一部分の事例にすぎない，繊維産業の製品あ るいは商品の開発対象は, 繊維素材, 加工製品化のプロ セス，技術，設備，市場までを包含すればすこぶる広範 多種にわたるものとなる、読者にとっては常識に過ぎな いことであろうが，以下開発対象となる繊維の新製品 （商品）について一応整理してみょう。すなわち，本号 では新製品とは何かという問いに対して説明しておきた W.

\section{A 、繊維素材の新製品}

衆知のごとく緎維（素材）は綟・麻・綿のような天然 繊維と化学繊維とがある。化学繊維は再生㵶維（たとえ ぱレーヨン), 半合成緎維（たとえばアセテート）, 合成緎 維（たとえばテトロン，ナイロン，アクリル、ビニロン, ポリプロ）に大別され，数十種類に分類される。これら 各種繊維素材は，衣料用，工業用，インテリア用などの 各使用分野にそれぞれの特長を発揮し，新用途を開拓し たり，競合代替，成長，衰退を続けている。天然械維以 外の繊維は人間が発明開発したもので，あるものは「天 然の絹を指向」あるものは「自然のウールを指向」して 研究開発に成功し工業的に生産されるようになった。研 究開発に成功した絨維素材はさらにより広い用途や使用 性能の向上をめぶして改良研究か続けられ続々と新品種 か開発されている，たとえば，強度を変える，伸度を変 える，収縮を変える，染色性を変える，風合いを変える， 光沢を変える，さらに制電，吸湿，防污，耐熱性などを 変える……などを目的として，ポリマーの開発（たとえ ば新しいポリマーの合成，分子構造や重合度の変化，第 3成分との共重合，ポリマーブレンドなど）や統系お 上U゙後好理段階の開発（たとえば結糸方式や機構の開発，

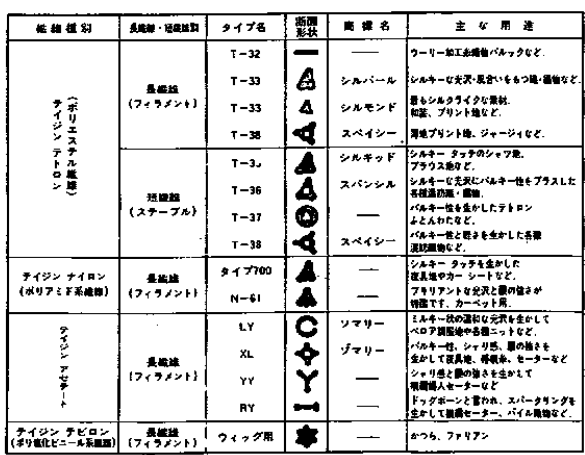

（第 1 図）異型断面系の種類(例) 
紡糸延伸や熱処理条件の開発など）がつぎつぎに行なわ れている。このようにして開発された一例として異形断 面系の代表的な種類を第 1 図に要約して示しておこう。

\section{B. 紡・織・染から二次製品までの開発}

上記 (1) では㵶維素材メーカーの製品開発，すなわち 原系，原綿の開発について概観したがこの素材瀻維は， 使用目的，使用分野に対応して，つぎの紡績・織物・ニ ット・染色などの加工段階を経て縫製段階にいたり，二 次製品化され，流通を経由してはじめて最終顧客に商品 として供給される。一般的に衣料用繊維彆品は第 2 図の ようなプロセスによって生産され販売される。

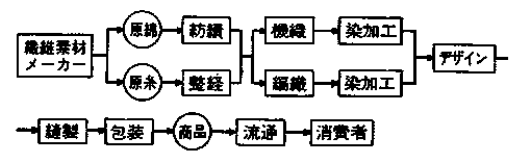

（第 2 図） 繊維製品生産プロセス

第 2 図の生産プロセスの各ステップごとに，その作業 内容は，それぞれの設備，技術ノウハウをもっており， その開発は企業の優位性を示すものであると同時に新製 品新商品の開発につながるものである. その一つ一つを 詳説する紙幅はないが素材から加工を経て檤彆（組立て） に移行するにつれ製品は高次化されシステム化されてく る. 最終段階の縫製は, 生産工程も製品もまさしくシス テムそのものである。一例として紳士ブレザーの生産工 程を第 3 図に示寸 (次ぺージ).
C．顧客 (消費者) から見な新製品

衣料の新製品は，生産 (新技術)・販売 (新市場)・市場 要求，て構成され，顧客の使用・消費によって開発活動 は終了するが, 衣料に対する顧客の要求は, 要約すれば 㙨能性，審美性，喍好性，流行性，コスト性などをあげ ることができる。しばしばいわれるごとく，衣料用繊維 製品は生活必需品的要素からライフ スタイル的要素に その比重が移行している. 文化の進歩, 所得の向上, 余 昵時間の増大，時代環境や条件の変化などにより，より カジェアル化 レジャー化，スポーツ化ファッション 化などのウエイトが增大している。しかし，このような ことは何も今日現代だけの現象ではなく，いつの時代に も衣料衣服に要求される多面的な要求である，時代とと もに，内容やレベルか変化したにすぎない。これを機能 ・効用・コンセプと呼んでもよいし，あるいは「もの」 と「意味」あるいは「ソフト」と「リード」または「は たらき」と「ありがたさ」……な゙と呼んでもよかろう。 これらについては項を改めて述べる。ただ本節でいいた いことは，顧客消費者の求めているものが，メーカー サイドの発想による素材や加工あるいは縫製の技術の新 しさ，製品の新しさのみではなく，消費者みずからの 個々の好みや個々の美，それぞれの価値の追求に大きな ウエイトが置かれているということである。このことは 消費者 1 人 1 人が生活者であり，生活システムのオルガ ナイザーであり，デザイナーであり開発者であるという ことである. 本人が意識するにしろ無意識にしろ，生活

（第 1 表）繊 維 製 品開発方向一覧 (一部)

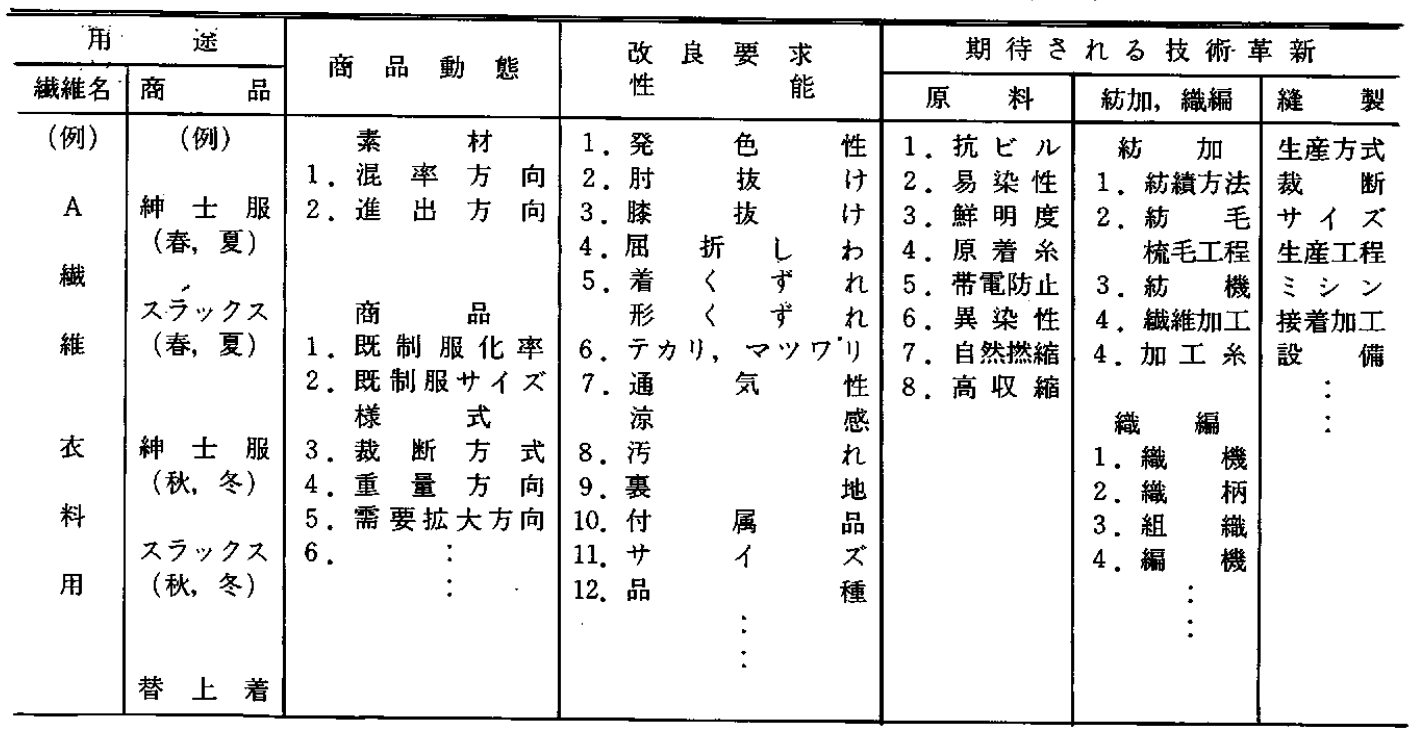




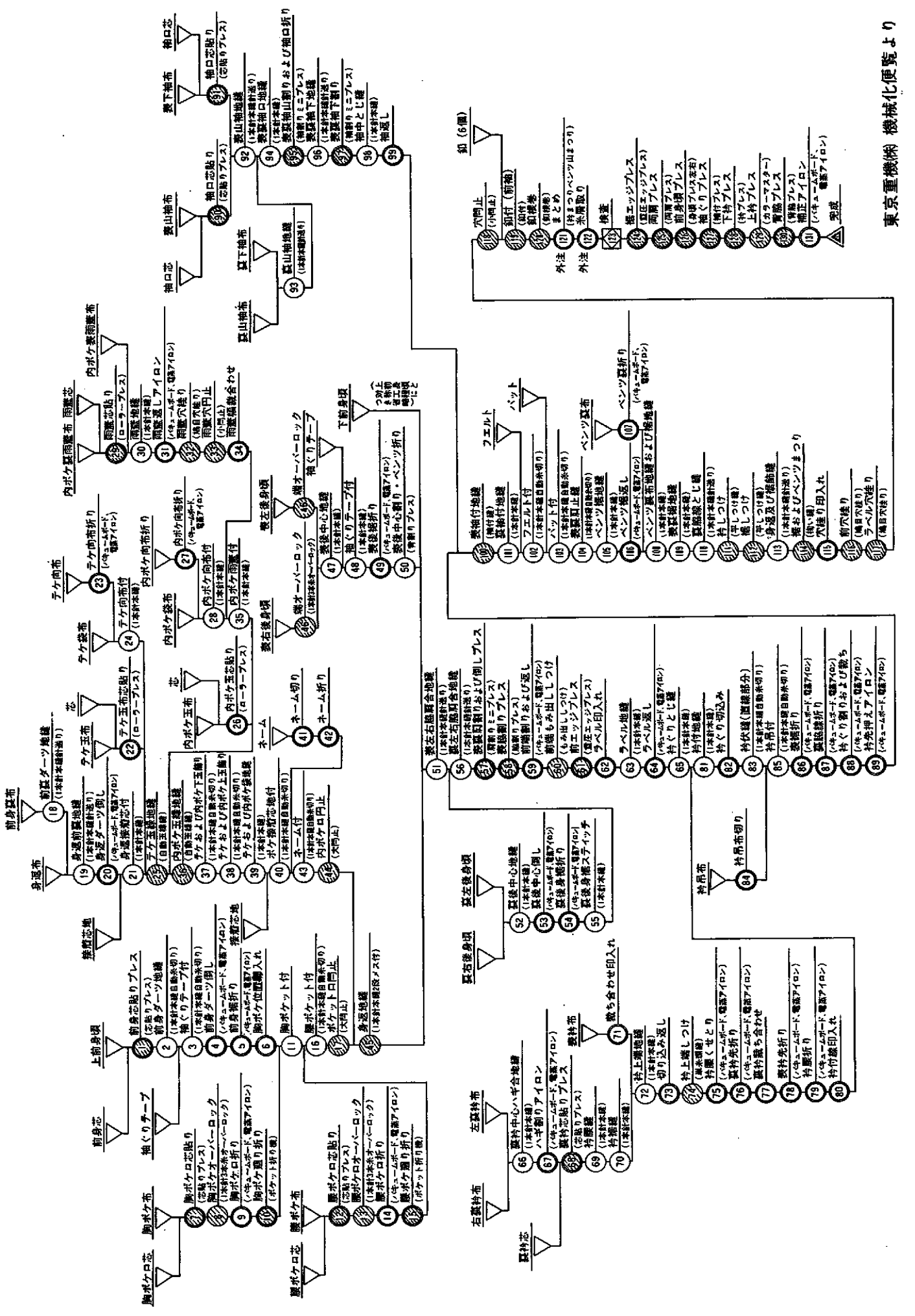

（第 3 図）紳士ブレザー工程分析表 
(裁維工学) Vol. 26, No. 9 (1973)

システムの中におけるサブ システムとしての服飾は， 消費者個人によって決められる。これは消費者 1 人 1 人 が新製品なり新商品の開発に倝加していることを意味す る. 誤解されないように付言するならば，一般には，メ 一カーで工業的に生産されるものを「新製品」といい, 工芸品にみられるように個々の創造開発は創作とか創作 品と呼ばれる. そして社外には関係なく，自社の立場か ら見て, 自社で初めて生産販売するものを新製品と㭔ぶ ケースも多い.

本号では，緎維の新製品といっても，素材メーカーの
立場，加工あるいは繾彆メ一カ一の立場，消費者の立場 からみていろいろな新製品の側面があることを述べた。 これらを要約すると.メーカーサイドの繊維鋚品の開 発方向は第 1 表のようなものである (47ページ)（ただ し一部のみ記載)。本号では製品, 商品, 新製品などの用 語を定我することなく使用したため読者に多分の混乱を 強いたようなことになったと思われるが，次号ではこれ らを整理しながら「新商品開発方法論」に逐次触れてゆ きたい. 